bones buried in the sand of the beaches where so many hundreds of whales have been flensed in former centuries.

In 1878 the accomplished historian of Guipuzcoa, Don Nicolas Soraluce, printed a pamphlet at Vitoria on "the origin and history of the whale and cod fisheries," which contains much interesting information. I may add that Señor Soraluce is preparing some additional chapters on the whale-fishery, and that be expects to obtain copies of interesting documents relating to the same subject from the archives of the Ministry of Marine at Madrid.

\section{A SYSTEM OF METEOROLOGICAL OBSER- VATIONS IN THE CHINA SEAS}

$\mathrm{T}$ a recent article in NATURE we referred to the proposal to establish an observatory at Hongkong under the superintendence of Major Palmer, R.E., and expressed a hope that Mr. Hart, of the Chinese Maritime Customs, would be successful in his efforts for the establishment of a number of meteorological stations along the coast of China. The China seas, on account of their numerous currents and destructive typhoons, are especially dangerous to shipping, and the value, in a material sense, of a thorough and accurate series of observations of this kind can hardly be overrated. Moved by these considerations, the Shanghai General Chamber of Commerce, the most numerous and influential foreign mercantile body in the Far East, has taken the matter in band, and at a recent meeting, reported in the Celestial Empire, discussed "the feasibility of organising a system of meteorological reports from the China coast and the interior, with the view of improving the knowledge of the origin and direction of storms, and warning mariners of their approach." The Chamber wisely consulted the Reverend Father Dechevrens, director of the Jesuits' Observatory at Siccawei, not far from Shanghai, who recommended that the object of the system should be twofold :-(I) To give shipmasters a sufficient knowledge of the meteorology of Chinese and Japanese waters to enable them at all times, and especially at critical moments, to recognise the best routes to follow in order to reach their destinations as speedily as possible, and emerge with credit from storms which they have been unable to avoid; and (2) to give vessels about to leave the port notice of the winds and weather they will probably meet during the subsequent twenty-four hours. The Siccawei Observatory will be able to accomplish both these ends, provided it receives the co-operation of the various shipmasters resorting to the coast of China. It is recommended that every vessel should be provided with a register in which at stated intervals during the day the conditions of the barometer and thermometer, the direction and force of the wind, and the quantity of rain are accurately recorded. In addition to these the various lighthouse keepers and officers at Custom stations along the coast should kecp a similar register. The director of the observatory will have in these numerous observations a basis on which to work, and his investigations and the result will be made public as widely as possible.

Father Dechevrens then proceeds to describe what is already known of the meteorology of the China seas. Two kinds of storms prevail there, those from the north, which may be called the storms of winter, or the northern monsoon, and the typhoons, which are, properly speaking, storms of summer, or the southern monsoon. The first come from the interior of Asia and travel towards the North Pacific from west to east, while the second generally remain confined to the neighbourhood of the Philippines, Formosa, and the Gulf of Tonquin. In order to study these storms more effectually, the observatory should receive, twice daily, meteorological observations from Manila, Hongkong, Amoy, Tientsin, Nagasaki, and Vladivostock. By these means warnings can be rapidly conveyed to and from Shanghai of storms coming either from the north or south. The observatory at Siccawei, moreover, should be connected by telephone with the foreign concession in Shanghai, and Father Dechevrens offers the services of one of his observers for the Shanghai end of the line. The Director concludes his Report with the observation that the work will not be one of a day, for everytbing is yet to be done. "The meteorology of these countries must be commenced at its foundation."

The recommendations contained in this Report were all adopted by the Chamber of Commerce, the members taking on themselves all the financial and business management of the undertaking. The owners of vessels and the Chinese Customs were called upon to supply the instruments necessary for observing, which were those recommended by the Meteorological Office in London, and already in use in some British mail steamers. The agent of the Great Northern Telegraph Company has promised to transmit the daily reports free of charge, and it is anticipated that the Chinese authorities and the local underwriters will contribute the funds necessary for carrying out the project.

Taken in conjunction with the establishment of a complete observatory in Hongkong, for which, as we have already mentioned, the Colonial Government has liberally provided, the scheme above described is one of much scientific and practical importance. Although several observatories are already in existence at various parts of the China seas, no combined attempt has been made to study systematically the meteorology of these regions. The project which has now been adopted by the Shanghai Chamber of Commerce helps to bring to a focus a number of observations which, taken singly, are of small value, but when collected and examined by competent scientific men, cannot fail to produce beneficial results

\section{THE AURORA ${ }^{1}$}

$$
\text { II. }
$$

$A S$ we have said, it was not uncommon at the Vega's winter quarters to see two or more auroral-arcs, one of which was generally the "common arc." The second was nearly parailel to it and separated from it by an unlighted space which was sometimes crossed by rays of light. It would be most important for a thorough knowledge of auroræ to know the true mutual position of the arcs; but here again simultaneous measurements at two distant places are necessary, and not having such, Nordenskjöld remarks that three suppositions may be made. First, that the two arcs have irregular positions with regard to one another; secondly, that they are superposed on one another, having their centres on the same axis perpendicular to the surface of the earth; and third, that their centres are on the same radius of the earth, and that they are situated in about the same plane. In all three cases the aspects of the arcs would be quite different. The observations at the Vega's wintering place prove that the last case is the rule, and that arcs irregularly situated with report to ore anotber, or crossing one another (which would correspond to the first and second supposition), are exceptions; and Nordenskjöld arrives at the conclusion that the auroræ-arcs which were seen from the Vega, were usually in about the same plane. It might be asked, however, if it were not more natural to suppose that both rings are at the same distance from the earth's surface, their centres being situated on the same radius of the earth? But on March 14 two parallel arcs appeared, and soon joined together into a broad belt, the interior edge of which was $5^{\circ}$, and the exterior one was $15^{\circ}$ above the horizon, both edges being quite concertric,

I A. E. Nordenskjöld, "Om ncrrskenen under Vegas öfvervintring vid, (The Scientific Work of the Vega Expedition, part r, pp. 40I-452.) Continued from p. 321 . 